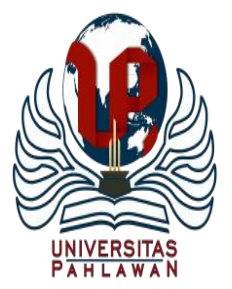

Jurnal Basicedu Volume 4 Nomor 4 Tahun 2020 Halaman 1350 - 1357

JURNAL BASICEDU

Research \& Learning in Elementary Education

https://jbasic.org/index.php/basicedu

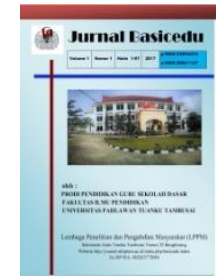

\title{
Upaya Meningkatkan Hasil Belajar Siswa Menggunakan Model Pembelajaran Discovery Learning di Sekolah dasar
}

\author{
Wilda Agnesia Panjaitan', Ester Julinda Simarmata ${ }^{2}$, Regina Sipayung ${ }^{3}$, Patri Janson Silaban ${ }^{4}$ \\ Universitas Katolik Santo Thomas, Sumatera Utara, Indonesia ${ }^{1,2,3,4,5}$ \\ E-mail : wildapjt21@gmail.com ${ }^{1}$ ejulinda@ymail.com² frederika_sip@yahoo.co.id ${ }^{3}$ \\ patri_silaban280388@yahoo.co.id ${ }^{4}$
}

\begin{abstract}
Abstrak
Penelitian ini bertujuan untuk mengetahui apakah dengan mengunakan model pembelajaran Discovery Learning dapat meningkatkan hasil belajar siswa pada Tema 1 Indahnya Kebersamaan di kelas IV SD Negeri 091626 Bandar Maratur Tahun Pembelajaran 2020/2021. Penelitian ini merupakan Penelitian Tindakan Kelas (PTK) yang dilaksanakan dalam dua siklus. Subjek dalam penelitian ini adalah siswa kelas IV yang berjumlah 21 siswa, terdiri dari 12 siswa laki-laki dan 9 siswa perempuan. Teknik pengumpulan data yang digunakan adalah observasi dan tes. Hasil penelitian ini menunjukkan adanya peningkatan hasil belajar siswa pada tema Indahnya Kebersamaan di kelas IV SD Negeri 091626 Bandar Maratur. Pada siklus II hasil observasi guru meningkat menjadi 90\% (baik sekali) dan hasil observasi terhadap kegiatan siswa juga meningkat menjadi 80 (baik sekali). Dengan demikian diperoleh simpulan bahwa dengan menggunakan model pembelajaran Discovery Learning terjadi peningkatan terhadap hasil belajar siswa pada tema Indahnya Kebersamaan di kelas IV SD Negeri 091626 Bandar Maratur Tahun Pembelajaran 2020/2021.
\end{abstract}

Kata kunci : hasil belajar siswa pada tema 1, model pembelajaran discovery learning

Abstract

This study is intended to find out if using the discovery learning model can improve students' learning on the mutual theme in fourth grade of SD Negeri 091626 Bandar Maratur years of 2020/2021. This study is a Class Action Research (CAR) conducted in two cycles. The subject of this study is the fourth grade of SD Negeri 091626 Bandar Maratur of 21 students, consisting of 12 male and 9 female. The data collection technique used was observation and testing. This study shows an increase in students' learning on the mutual theme in fourth grade of SD Negeri 091626 Bandar Maratur. Further from observing the teacher's activities in carrying out learning on cycle 1 comes an average of 62 (sufficient) and observation of students activities gained an average of 62 (sufficient). On the cycle 2 the results of teacher observation increased to 90\% (excellent) and the results of observation on students activities also increased 80\%. The conclusion is that using discovery learning model, there is an increase in the students' learning results on the mutual theme in the fourth grade of SD Negeri 091626 Bandarmaratur years 2020/2021.

Keywords : great mutual theme 1, learning model of discovery learning

Copyright (c) 2020 Wilda Agnesia Panjaitan, Ester Julinda Simarmata, Regina Sipayung, Patri Janson Silaban

$\triangle$ Corresponding author

Address : Kota Kupang

Email : syahrul@unmuhkupang.ac.id

ISSN 2580-3735 (Media Cetak)

Phone : 082337060959

ISSN 2580-1147 (Media Online)

DOI: https://doi.org/10.31004/basicedu.v4i4.549 
1351 Upaya Meningkatkan Hasil Belajar Siswa Menggunakan Model Pembelajaran Discovery Learning di Sekolah Dasar- Wilda Agnesia Panjaitan, Ester Julinda Simarmata, Regina Sipayung, Patri Janson Silaban

DOI: https://doi.org/10.31004/basicedu.v4i4.549

\section{PENDAHULUAN}

Menurut Undang-Undang Nomor 20 Tahun 2003 tentang Sistem Pendidikan Nasional, Bab 1 Pasal 1 ayat (1) dikemukakan bahwa pendidikan adalah usaha sadar dan terencana untuk mewujudkan suasana belajar dan proses pembelajaran agar peserta didik secara aktif mengembangkan potensi dirinya untuk memiliki kekuatan spiritual keagamaan, pengendalian diri, kepribadian, kecerdasan, akhlak mulia, serta keterampilan yang diperlukan dirinya, masyarakat, bangsa, dan negara.

Pendidikan bukanlah suatu hal yang statis atau tetap, melainkan suatu yang dinamis, sehingga menuntut adanya suatu perubahan atau perbaikan secara terus menurus. Pendidikan yang berkualitas dapat diwujudkan dengan kegiatan pembelajaran di sekolah yang dapat meningkatkan kemampuan pengetahuan, keterampilan, dan sikap peserta didik. Oleh karena itu pendidikan merupakan hal yang terpenting dalam kehidupan manusia untuk menjadi lebih baik lagi ke depannya.

Demi tercapainya pendidikan yang bermutu dan berkualitas, maka pemerintah mulai mengembangkan kurikulum baru yaitu Kurikulum 2013. Pada kurikulum 2013 pembelajaran tematik adalah pembelajaran yang dirancang berdasarkan tema-tema tertentu untuk mengaitkan beberapa mata pelajaran sehingga dapat memberikan pengalaman bermakna kepada peserta didik.

Pembelajaran tematik juga menekankan keterlibatan peserta didik dalam belajar dan keterlibatan siswa dalam memecahkan suatu masalah, sehingga hal ini dapat menumbuhkan kreativitas dan keaktifan siswa sesuai dengan potensi mereka yang berbeda satu dengan yang lainnya.

Dalam proses pembelajaran, siswa kurang berpartisipasi aktif dan siswa saling berinteraksi antar teman pada saat proses pembelajaran di kelas tanpa memperhatikan guru di depan kelas. Dengan demikian, dapat dilihat pada tabel di bawah ini dimana hasil belajar siswa pada Tema 1 Indahnya Kebersamaan di kelas IV SD Negeri 091626 Bandar Maratur masih banyak yang belum mencapai nilai Kriteria Ketuntasan Minimum (KKM) yang ditentukan yaitu 70. Diperoleh keterangan bahwa masih banyak siswa yang mengalami kesulitan untuk memahami materi pembelajaran tematik, dan minat belajar siswa kurang dalam mengikuti proses pembelajaran tematik. Akibat dari kesulitan memahami pembelajaran tematik, maka diperoleh hasil belajar siswa tergolong rendah. Hal ini dapat dilihat dari hasil nilai ulangan harian mata pelajaran tema 1 Indahnya Kebersamaan tahun pembelajaran 2019/2020.

Tabel 1 Hasil Nilai Ulangan Harian Tema 1 Indahnya Kebersamaan

\begin{tabular}{lllll}
\hline $\begin{array}{l}\text { Mata } \\
\text { Pelajaran }\end{array}$ & NKM & Jumlah & $(\%)$ & $\begin{array}{l}\text { Keterangan } \\
\text { siswa }\end{array}$ \\
\hline PKn & $>70$ & 7 & $39 \%$ & Tuntas \\
& $<70$ & 11 & $61 \%$ & Tidak Tuntas \\
Bahasa & $>70$ & 5 & $28 \%$ & Tuntas \\
Indonesia & $<70$ & 13 & $72 \%$ & Tidak Tuntas \\
IPA & $>70$ & 8 & $44 \%$ & Tuntas \\
& $<70$ & 10 & $56 \%$ & Tidak Tuntas \\
\hline
\end{tabular}


1352 Upaya Meningkatkan Hasil Belajar Siswa Menggunakan Model Pembelajaran Discovery Learning di Sekolah Dasar- Wilda Agnesia Panjaitan, Ester Julinda Simarmata, Regina Sipayung, Patri Janson Silaban

DOI: https://doi.org/10.31004/basicedu.v4i4.549

Dari permasalahan yang dihadapi maka dapat disimpulkan bahwa banyak faktor yang mempengaruhi rendahnya hasil belajar siswa. Salah satu upaya mengatasi permasalahan ini, peneliti harus mampu merancang model pembelajaran dan media pembelajaran yang bermakna bagi siswa. Untuk itu peneliti harus kreatif dalam mendesain model pembelajaran dan media pembelajaran yang memungkinkan siswa dapat berpartisipasi aktif dan kreatif terhadap materi yang diajarkan.

Untuk itu model pembelajaran Discovery Learning perlu digunakan dalam proses pembelajaran agar dapat meningkatkan penguasaan materi yang telah diajarkan dan siswa dapat mencapai hasil belajar yang diharapkan.

Menurut (Kodir, 2018: 100), pembelajaran discovery learning adalah model pembelajaran yang mengatur sedemikian rupa sehingga siswa memperoleh pengetahuan yang belum diketahuinya, baik sebagian mupun seluruhnya ditemukan sendiri. Dalam pembelajaran ini, mulai dari strategi sampai dengan jalan dan hasil penemuan ditemukan oleh siswa.

Menurut (Putrayasa et al., 2014: 3) model Discovery Learning adalah suatu tipe pembelajaran dimana siswa membangun pengetahuan mereka sendiri dengan mengadakan suatu percobaan dan menemukan sebuah prinsip dari hasil percobaan tersebut. Dalam penerapan model Discovery Learning ini, guru membagi kelas menjadi kelompok-kelompok dengan anggota 4 atau 6 siswa yang heterogen. Kelompok dibentuk dengan mempertimbangkan keakraban, kecerdasan persahabatan atau minat yang berbeda. Hal ini didukung oleh penelitian yang di lakukan (Wulandari et al., 2018) Upaya Peningkatan Keaktifan Siswa dan Hasil Belajar Tematik Melalui Model Pembelajaran Discovery Learning Berbantuan Puzzle pada Siswa Kelas 5 SDN Sidorejo Kidul 2 T.A 2017/2018.

\section{METODE}

Penelitian ini dilakukan dengan menggunakan pendekatan campuran melalui metode Penelitian Tindakan kelas (PTK). Pendekatan campuran merupakan gabungan dari pendekatan kualitatif dan pendekatan kuantitatif. Pendekatan kualitatif dan pendekatan kuantitatif memiliki beberapa persamaan, oleh karena itu ada kecendrungan untuk menggabungkan pendekatan kualitatif dan pendekatan kuantitatif yang dikenal dengan pendekatan campuran.

Sedangkan metode yang digunakan dalam penelitian ini adalah metode Penelitian Tindakan

Kelas (PTK). Menurut (Aqib, 2016: 3) mengatakan bahwa Penelitian Tindakan Kelas (PTK) adalah penelitian yang dilakukan oleh guru kelasnya sendiri melalui refleksi diri dengan tujuan untuk memperbaiki kinerjanya sehingga hasil belajar ia meningkat. Selanjutnya menurut (Ananda, 2015: 20) mengatakan bahwa PTK merupakan penelitian yang dilakukan dalam rangka meningkatkan atau memperbaiki mutu praktek pembelajaran yang dilakukan secara sistematis mulai dari perencanaan sampai refleksi diri untuk meningkatkan kualitas pembelajaran. 
1353 Upaya Meningkatkan Hasil Belajar Siswa Menggunakan Model Pembelajaran Discovery Learning di Sekolah Dasar- Wilda Agnesia Panjaitan, Ester Julinda Simarmata, Regina Sipayung, Patri Janson Silaban

DOI: https://doi.org/10.31004/basicedu.v4i4.549

Menurut (Purwanto, 2011: 114), validitas berhubungan dengan kemampuan untuk mengukur secara tepat sesuatu yang diinginkan diukur. Data evaluasi yang baik sesuai dengan kenyataan disebut data valid. Agar instrumen yang dibuat oleh peneliti dapat dikatakan valid maka dilakukan uji validitas. Validitas dalam penelitian ini dilakukan dengan diuji dan diperiksa validitasnya, sehingga data tersebut dapat dipertanggung jawabkan. Untuk menjamin validitas ini maka semua pertanyaan disusun berdasarkan kajiankajian teori yang berkaitan dengan permasalahan. Cara yang digunakan untuk mengetahui tingkat validitas instrument pada penelitian ini adalah menggunakan rumus korelasi product moment, sebagai berikut:

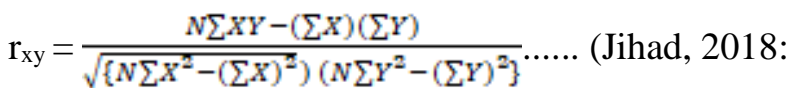
180)

\section{Keterangan:}

$r_{x y}=$ Koefisien korelasi antara variabel $\mathrm{X}$ dan $\mathrm{Y}$

$\mathrm{N}$ = Banyaknya peserta tes

$\mathrm{X}=$ Nilai hasil uji coba

$\mathrm{Y}=$ Nilai rata-rata siswa

Reliabilitas soal merupakan ukuran yang menyatakan tingkat keajegan atau kekonsistenan suatu soal tes. Untuk mengukur tingkat keajegan soal ini, rumus yang digunakan sebagai berikut:

$\mathrm{r}_{11}=\left(\frac{n}{n-1}\right)\left(\frac{S^{2}-\sum p q}{S^{2}}\right) \ldots \ldots \ldots \ldots($ Jihad, 2018: 180)

\section{Keterangan:}

$\mathrm{r}_{11}=$ Reliabilitas secara keseluruhan

$\mathrm{n}=$ Banyaknya item dalam soal $\sum p q=$ Jumlah hasil perkalian antara $\mathrm{p}$ dan $\mathrm{q}$

$s^{2} \quad=$ Standar devisiasi tes

1. Ketuntasan Individual

Setiap siswa dikatakan tuntas belajarnya (ketuntasan individual) jika nilai yang diperoleh siswa telah mencapai nilai KKM 70, karena nilai KKM yang ditetapkan di sekolah yaitu 70. Untuk menentukan ketuntasan belajar siswa (individual) dapat dihitung menggunakan persamaan sebagai berikut :

$\mathrm{KB}=\frac{T}{T_{t}} \mathrm{X} 100 \%$ (Trianto, 2018: 241)

Dimana keterangannya sebagai berikut :

$\mathrm{KB}=$ ketuntasan belajar

$\mathrm{T}=$ jumlah skor yang diperoleh siswa

$\mathrm{Tt}=$ jumlah skor total

2. Ketuntasan Klasikal

Suatu kelas dikatakan tuntas belajarnya (ketuntasan secara klasikal) jika dalam kelas tersebut terdapat $\geq 75 \%$ siswa yang telah tuntas belajarnya dari nilai KKM yang telah ditetapkan di sekolah yaitu 70 (Trianto, 2018: 241).

$$
\mathrm{P}=\frac{\sum \text { siswa yang tuntas belajar }}{\sum \text { siwa }} \times 100 \%
$$

Keterangan :

$\mathrm{P}=$ Presentasi ketuntasan belajar

$\sum$ siswa yang tuntas $=$ Jumlah siswa yang tuntas belajar

Esiswa $\quad=$ Jumlah semua siswa 
1354 Upaya Meningkatkan Hasil Belajar Siswa Menggunakan Model Pembelajaran Discovery Learning di Sekolah Dasar- Wilda Agnesia Panjaitan, Ester Julinda Simarmata, Regina Sipayung, Patri Janson Silaban

DOI: https://doi.org/10.31004/basicedu.v4i4.549

3. Rata-Rata Hasil Belajar

Peneliti menjumlahkan nilai yang diperoleh siswa, sebelumnya dibagi dengan jumlah siswa kelas tersbut sehingga diperoleh nilai rata-rata. Nilai rata-rata ini didapat dengan menggunakan rumus :

$\mathrm{X}=\frac{\sum X}{\sum N} \ldots \ldots \ldots . . .($ Aqib, 2016: 40)

Keterangan :

$\mathrm{X}=$ nilai rata-rata

$\sum X=$ jumlah semua nilai siswa

$\sum N=$ jumlah siswa

\section{Prosedur Penelitian}

Desain penelitian tindakan kelas berupa refleksi awal dan observasi untuk mengidentifikasi permasalahan dalam kelas, dilanjutkan dengan pelaksanaan penelitian tindakan kelas (PTK) selama 2 siklus. Rancangan penelitan ini adalah Penelitian Penelitian Tindakan Kelas (PTK). Secara garis besar untuk melaksanakan penelitian tindakan kelas ada empat tahap yang harus dilaksanakan yaitu, (1) perencanaan, (2) pelaksanaan, (3) pengamatan, dan (4) refleksi menurut (Ananda, 2015: 47).

\section{HASIL DAN PEMBAHASAN}

Berdasarkan kesulitan dan kurang maksimalnya hasil dari pelaksanaan pembelajaran dengan menggunakan model pembelajaran Discovery learning pada siklus I, maka peneliti melakukan perbaikan pada siklus II ini dengan cara memperbaiki, penyampaian tujuan pembelajaran dengan jelas dan terarah agar siswa lebih paham dalam proses belajar mengajar sesuai dengan materi pembelajaran, dan peneliti memotivasi siswa agar lebih aktif dalam proses pembelajaran dan peneliti belajar memahami karakteristik mereka sehingga kelas lebih terarahkan sehingga proses pembelajaran berjalan dengan baik dan disiklus ini siswa sudah tuntas belajarnya, maka penelitian tidak dilanjutkan ke siklus berikutnya.

Berdasarkan data yang diperoleh dari aktivitas guru pada siklus I dan siklus II dapat dilihat adanya peningkatan. Dimana pada siklus I hasil observasi aktivitas guru diperoleh sebesar $60 \%$ dengan kriteria cukup dan siklus II meningkat menjadi $88 \%$ dengan kriteria sangat baik. Berdasarkan peningkatan kedua siklus ini dapat dilihat bahwa dari siklus I ke siklus II terdapat peningkatan sebesar $28 \%$.

Untuk lebih jelas mengenai peningkatan hasil dari observasi aktivitas siswa dapat dilihat pada gambar grafik di bawah ini:

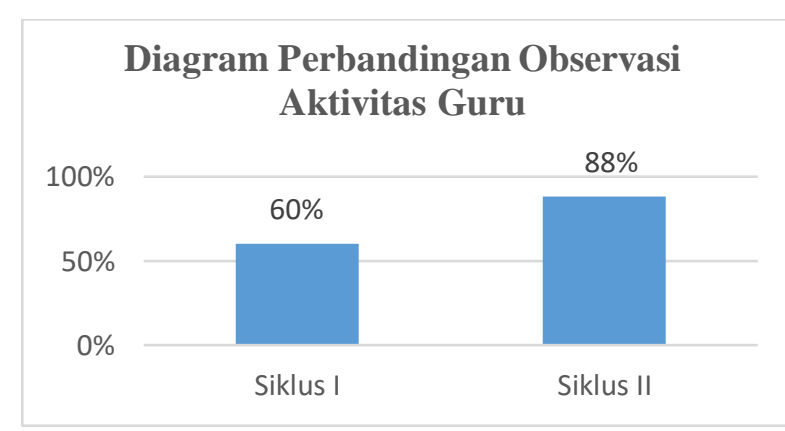

Diagram 1. Perbandingan Hasil Observasi Aktivitas Guru Siklus I dan Siklus II Aktivitas Siswa Siklus I dan Siklus II

Berdasarkan data yang diperoleh dari hasil belajar siswa dalam pelaksanaan penelitian yang 
1355 Upaya Meningkatkan Hasil Belajar Siswa Menggunakan Model Pembelajaran Discovery Learning di Sekolah Dasar- Wilda Agnesia Panjaitan, Ester Julinda Simarmata, Regina Sipayung, Patri Janson Silaban

DOI: https://doi.org/10.31004/basicedu.v4i4.549

dimulai dari pelaksanaan pra-test, post test siklus I dan post test siklus II dapat dilihat bahwa terdapat peningkatan hasil belajar dari pra-test, ke post test siklus I dan ke post test siklus II. Ketuntasan hasil belajar secara klasikal pada pra-test diperoleh sebesar $28,57 \%$. Pada post test siklus I ketuntasan hasil belajar meningkat menjadi $42,85 \%$. Pada post test siklus II ketuntasan hasil belajar meningkat menjadi $85,71 \%$. Peningkatan hasil belajar dari pra-test ke posttest siklus I adalah sebesar 14,28\% dan peningkatan hasil belajar dari siklus I ke siklus II adalah sebesar $42,46 \%$. Untuk lebih jelasnya dapat dilihat pada grafik di bawah ini:

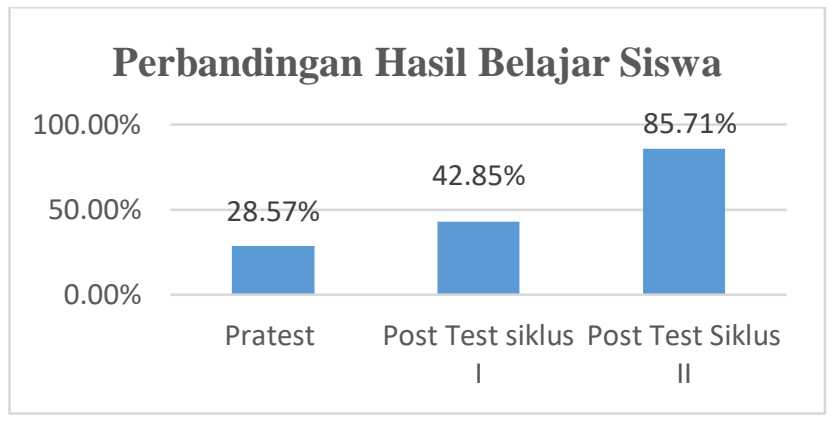

Diagram 2. Perbandingan Hasil Belajar Siswa

Berdasarkan data yang diperoleh dari ratarata hasil belajar pada pra-test, posttest siklus I dan posttest siklus II dapat dilihat adanya peningkatan. Pada pra-test rata-rata hasil belajar diperoleh sebesar 53,61 sedangkan pada posttest siklus I rata-rata hasil belajar meningkat menjadi 64,42 kemudian pada posttest siklus II rata-rata hasil belajar meningkat menjadi 80,19. Berdasarkan peningkatan yang diperoleh dari data hasil belajar siswa maka dapat dilihat bahwa dari pra-test ke posttest siklus I mengalami peningkatan sebesar 10,81 dan dari pos test siklus I ke post test siklus II mengalami peningkatan sebesar 15,77.
Untuk lebih jelas mengenai peningkatan rata-rata hasil belajar siswa dapat dilihat pada gambar diagram di bawah ini:

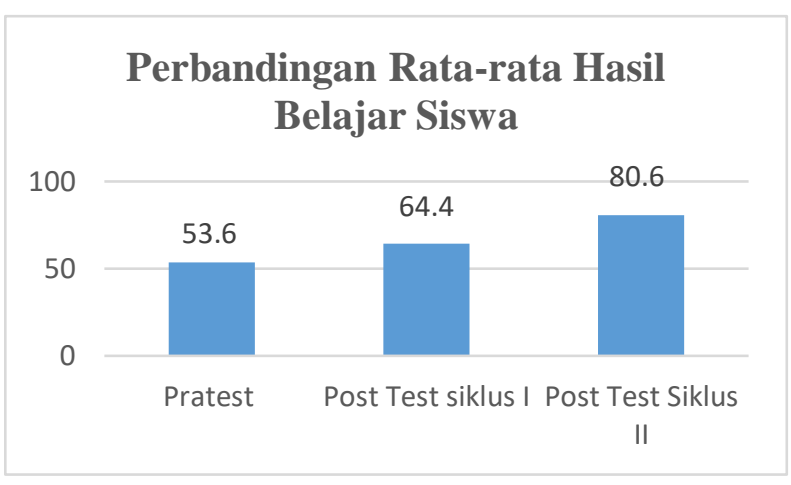

Diagram 3. Rata-rata Hasil Belajar Siswa

Dapat dilihat bahwa siswa yang tuntas hasil belajarnya pada posttest siklus I terdapat 9 orang siswa yang tuntas $(42,85 \%)$ dan siswa yang tidak tuntas hasil belajarnya sebanyak 12 orang siswa (57,14\%). Pada pos test siklus II, diperoleh hasil belajar siswa dari 21 orang jumlah siswa terdapat sebanyak 18 orang siswa yang tuntas hasil belajarnya $(85,71 \%)$ sedangkan yang tidak tuntas hasil belajarnya sebanyak 3 orang siswa $(14,28 \%)$. Untuk lebih jelasnya tentang peningkatan hasil belajar siswa dari posttest siklus I, sampai dengan posttest siklus II dapat dilihat pada tabel di bawah ini :

Tabel 2. Hasil Belajar Siswa Secara Klasikal

\begin{tabular}{ccc}
\hline No & Jenis Tes & esentase Ketuntasan Klasik \\
\hline 1 & Pratest & $28,57 \%$ \\
2 & Posttest siklus I & $42,85 \%$ \\
3 & Posttest siklus II & $85,71 \%$ \\
\hline
\end{tabular}

Hasil dari tabel diatas menunjukkan bahwa nilai siswa mengalami peningkatan dari 
1356 Upaya Meningkatkan Hasil Belajar Siswa Menggunakan Model Pembelajaran Discovery Learning di Sekolah Dasar- Wilda Agnesia Panjaitan, Ester Julinda Simarmata, Regina Sipayung, Patri Janson Silaban

DOI: https://doi.org/10.31004/basicedu.v4i4.549

dilaksanakannya posttest setiap siklus. Peningkatan hasil belajar siswa pada subtema Kebersamaan dalam Keberagaman ini dapat dilihat pada gambar grafik dibawah ini:

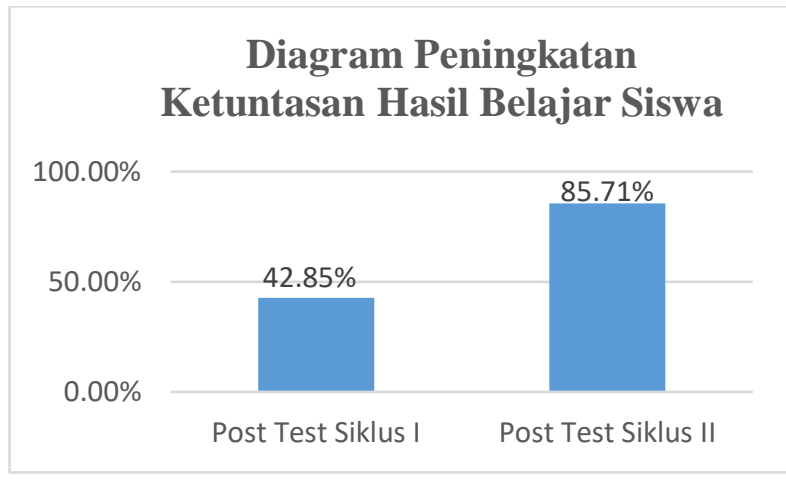

Diagram 4. Peningkatan Ketuntasan Hasil Belajar Siswa pada Posttest Siklus I dan Posttest Siklus II

Dari diagram di atas dapat dilihat bahwa pada pelaksanaan posttest siklus I ketuntasan hasil belajar siswa diperoleh sebesar $42,85 \%$, tetapi ketuntasan hasil belajar ini belum mencapai kriteria ketuntasan klasikal yaitu 75\%. Siswa yang dikatakan tuntas hasil belajarnya jika terdapat $75 \%$ dari jumlah siswa yang mendapat nilai tuntas atau mencapai Kriteria Ketuntasan Minimal (KKM) yaitu 70. Oleh karena itu, penelitian dilanjutkan ke siklus II. Pada posttest siklus II hasil belajar siswa meningkat menjadi $85,71 \%$ dan mencapai kriteria ketuntasan secara klasikal, karena sudah mencapai kriteria ketuntasan secara klasikal maka penelitian ini tidak perlu dilanjutkan ke siklus selanjutnya.

Dari pembahasan data yang diperoleh peneliti dapat dilihat bahwa terdapat peningkatan hasil belajar yang baik dari siklus I ke siklus II. Penelitian ini dikatakan berhasil apabila ketuntasan hasil belajar siswa secara klasikal mencapai $75 \%$ dan pada siklus II diperoleh ketuntasan hasil belajar secara klasikal sebesar $85,71 \%$. Jadi dapat disimpulkan bahwa melalui temuan yang telah diperoleh peneliti dapat memberikan jawaban terhadap hipotesis tindakan yang telah dikemukakan sebelumnya bahwa dengan penerapan model pembelajaran Discovery Learning terjadi peningkatan terhadap hasil belajar siswa pada tema Indahnya Kebersamaan pada subtema Kebersamaan Dalam Keberagaman pada pembelajaran 3 dan pembelajaran 4 di kelas IV SDN 091626 Bandar Maratur.

\section{SIMPULAN}

Berdasarkan hasil penelitian dan pembahasan mengenai meningkatkan hasil belajar siswa dengan menggunakan model pembelajaran Discovery Learning pada tema Indahnya Kebersamaan di kelas IV SDN 091626 Bandar Maratur, dapat disimpulkan bahwa:

a) Penerapan model pembelajaran Discovery Learning dapat meningkatkan keterampilan guru pada pembelajaran tema Indahnya Kebersamaan di kelas IV SDN 091626 Bandar Maratur. Hal ini dapat dilihat dari hasil observasi keterampilan guru selama penelitian yang menunjukkan adanya peningkatan persentase pada tiap siklusnya, yaitu pada siklus I hasil observasi aktivitas guru diperoleh dengan jumlah 30 dengan persentase $60 \%$ dan kriteria cukup, pada siklus II meningkat menjadi 28 dengan persentase $88 \%$ dan kriteria baik sekali. Sedangkan untuk aktivitas siswa juga mengalami peningkatan. Hal ini dapat 
1357 Upaya Meningkatkan Hasil Belajar Siswa Menggunakan Model Pembelajaran Discovery Learning di Sekolah Dasar- Wilda Agnesia Panjaitan, Ester Julinda Simarmata, Regina Sipayung, Patri Janson Silaban

DOI: https://doi.org/10.31004/basicedu.v4i4.549

dilihat dari peningkatan skor 37 dengan nilai 62 dan kriteria cukup dan pada siklus II meningkat dengan mendapat perolehan skor 48 dengan nilai 80 dan kriteria baik.

b) Penerapan model pembelajaran Discovery Learning dapat meningkatkan hasil belajar siswa pada tema Indahnya Kebersamaan dengan sub tema Kebersamaan dalam Keberagaman di kelas IV SDN 091626 Bandar Maratur. Hal ini dibuktikan dengan adanya peningkatan persentase ketuntasan klasikal hasil belajar siswa dan rata-rata hasil belajar siswa yang diperoleh pada setiap siklus. Pada pre test (tes awal) diperoleh ketuntasan klasikal sebesar $28,57 \%$ dengan rata-rata nilai siswa 53,61. Pada post test siklus I ketuntasan belajar secara klasikal meningkat menjadi $42,85 \%$ dengan rata-rata nilai siswa 64,42 dan persentase ketuntasan hasil belajar siswa secara klasikal meningkat juga pada post test siklus II menjadi $85,71 \%$ dengan ratarata nilai siswa 80,2.

Dari kesimpulan di atas dapat diketahui bahwa hipotesis tindakan dari penelitian ini telah terjawab, yaitu dengan menggunakan model pembelajaran Discovery Learning terjadi peningkatan hasil belajar siswa pada tema Indahnya Kebersamaan di kelas IV SDN 091626 Bandar Maratur.

\section{DAFTAR PUSTAKA}

Ananda, S. (2015). Penelitian Tindakan Kelas. Cipta Pustaka Media.
Aqib, Z. dkk. (2016). Penelitian Tindakan Kelas. Rama Widya.

Arifin, Z. (2016). Evaluasi Pembelajaran. Rosda.

Arikunto. (2017). Dasar-Dasar Evaluasi Pendidikan. Bumi Aksara.

Astuti, M. S. (2015). Peningkatan Keterampilan Bertanya Dan Hasil Belajar Siswa Kelas 2 Sdn Slungkep 03 Menggunakan Model Discovery Learning. Scholaria: Jurnal Pendidikan Dan Kebudayaan, 5(1), 10.

Bahari, N. K. I., Darsana, I. W., \& Putra, D. K. N. S. (2018). Pengaruh Model Discovery Learning Berbantuan Media Lingkungan Alam Sekitar terhadap Hasil Belajar IPA. Jurnal Ilmiah Sekolah Dasar, 2(2), 103.

Irsan. (2019). Jurnal basicedu. Jurnal Basicedu, $3(2), 8$.

Jihad, H. (2018). Evaluasi Pembelajaran. Multi Pressindo.

Kadir, A. (2018). Pembelajaran Tematik. PT Rajagrafindo Persada.

Khairani. (2017). Psikologi Belajar. Aswaja Pressindo.

Kodir, A. (2018). Manajemen Pembelajaran Saintifik Kurikulum 2013 Pembelajaran Berpusat Pada Siswa. CV Pustaka Setia.

Lumban, R., Ester, G., \& Simarmata, J. (2019). Vol. 3 No. 4 September 2019. 3(4), 342-348.

Marta, F., Simorangkir, A., Tanjung, D. S., \& Intelligences, P. M. (2019). Pendekatan Multiple Intelligences Berbasis Budaya. 7(4), 302-304.

Purwanto. (2011). Evaluasi Hasil Belajar. Pustaka Pelajar.

Sidiq, M. A., \& Prasetyo, T. (2020). Efektivitas Model Pembelajaran Problem Solving dan Discovery Learning Terhadap Kemampuan Berpikir Kritis Siswa Sekolah Dasar. Jurnal Basicedu, 4(2), 361-370. 